\title{
Heavy metal assessment and water quality values in urban stream and rain water
}

\author{
${ }^{1}$ K. Sekabira; ${ }^{2}$ H. Oryem Origa; ${ }^{3}$ T. A. Basamba; ${ }^{2}$ G. Mutumba; ${ }^{2}$ E. Kakudidi \\ ${ }^{1}$ Department of Environment, Faculty of Science and Engineering, Kampala International University, \\ Kampala, Uganda \\ ${ }^{2}$ Department of Botany, Faculty of Science, Makerere University, Kampala, Uganda \\ ${ }^{3}$ Department of Soil Science, Faculty of Agriculture, Makerere University, Kampala, Uganda
}

Received 2 April 2010; $\quad$ revised 14 June 2009; accepted 21 July 2010; available online 1 September 2010

\begin{abstract}
Water quality monitoring in developing countries is inadequate, especially in stream water affected by urban effluents and runoff. The purpose of this study was to investigate heavy metal contaminants in the Nakivubo Stream water in Kampala, Uganda. Water samples Nakivubo Channelized Stream, tributaries and industrial effluents that drain into the stream were collected and analysed for the total elemental concentration using flame atomic absorption spectrophotometer. The results showed that: 1 ) the wastewater was highly enriched with lead and manganese above the maximum permissible limit; 2) the levels of dissolved oxygen were below the maximum permissible limit, while the biological oxygen demand was above the maximum permissible limit. All industrial effluents/wastewater were classified as strong (> $220 \mathrm{mg} / \mathrm{L}$ ). Factor analysis results reveal two sources of pollutants; 1) mixed origin or chemical phenomena of industrial and vehicular emissions and 2) multiple origin of lead (vehicular, commercial establishment and industrial). In conclusion, Nakivubo Channelized Stream water is not enriched with heavy metals. These heavy metals (lead, cadmium and zinc) were rapidly removed by co-precipitation with manganese and iron hydroxides and total dissolved solids into stream sediments. This phenomena is controlled by $\mathrm{pH}$ in water.
\end{abstract}

Keywords: Co-precipitation; Factor analysis; Industrial emission; Nakivubo; Water quality

\section{INTRODUCTION}

Heavy metal contamination of stream and river water ecosystem is a worldwide environmental problem. Trace amounts of heavy metals are always present in fresh waters from the weathering of rocks and soils (Muwanga, 1997; Anderson, 2003; Babel and Opiso, 2007; Samarghandi et al., 2007; Igwe et al., 2008; Al-Juboury, 2009). Recently, water quality monitoring has become a matter of concern in stream and river water systems affected by careless disposal of urban effluents. Runoff, atmospheric deposition and domestic and industrial effluent discharges are the major sources of aquatic pollution (Wasswa, 1997; Linnik and Zubenko, 2000; Campbell, 2001; Lwanga et al., 2003 and Lomniczi et al., 2007) and physicochemical characteristics such as dissolved oxygen and the $\mathrm{pH}$ of aquatic ecosystems may determine

\footnotetext{
$\bar{\triangle}$ *Corresponding Author Email: ssekaba@gmail.com
} Tel.: +256 772855 348; Fax: +256 414501974 stream water ecosystem integrity. Monitoring of stream water physico-chemical characteristics and heavy metal concentration is necessary to establish the levels of contamination in wastewater. With increasing urbanisation and industrialization, there has been a rapid increase in industrial effluent discharge into the stream water, leading to increased pollution load. In aquatic eco-systems, trace elements may be immobilised within the stream water and may involve complex formation and co-precipitation as oxides and hydroxides of Fe, Mn or may occur in particulate form (Awofolu et al., 2005; Mwiganga and Kansiime, 2005; Nyangababo et al, 2005b; Srivastava et al., 2008).

The Nakivubo Channelized Stream is the major recipient of runoff and a surrogate end point for organic substances of industrial and domestic effluents (Kansiime et al., 1995; Sentongo, 1998). The Nakivubo channel is increasingly being polluted with direct 
discharge of raw industrial effluent, untreated sewage and wastewater from commercial, industrial and domestic establishments. The Nakivubo Channelized Stream is important because it was constructed primarily to minimize flooding in the city, but is also being used for fishing, farming, washing and as a source of drinking water. The amount of point source pollutant effluents for this channel may affect the Ggaba water treatment plant quality intake since it is only $4 \mathrm{~km}$ away (Sentongo, 1998). In the upstream, the flow rate is very low and water in the channel has a dark colour characterized by bad odour of decaying organic matter during dry periods. The smell is augmented by sewage effluent discharge from the National Water and Sewage Corporation (NWSC) plant, city abattoir and residential and commercial establishments into the channel. The objects of the present work were to; 1 ) assess heavy metal concentration and contamination in the Nakivubo Channelized stream water 2) investigate the relationship among heavy metals and physico-chemical characteristics and 3) determine the common origin of the contaminants using Factor and Cluster analyses. This study was conducted during August, 2008 to November 2009, along the Nakivubo Channelized stream, Kampala Uganda.

\section{MATERIALSAND METHODS}

Study area and sampling sites

The Nakivubo Channelized Stream, originating from

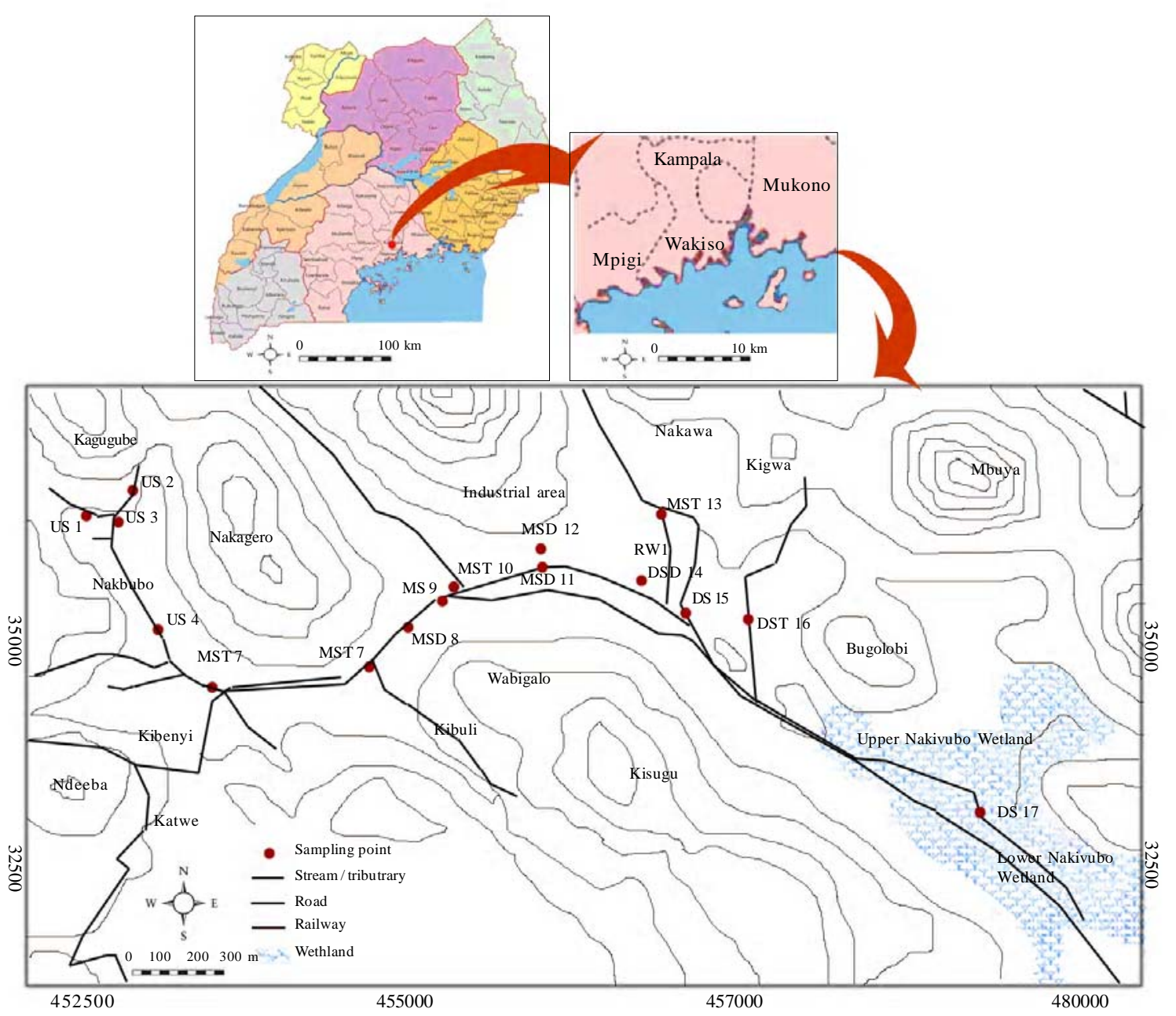

Fig. 1: Map showing the locations of the sampling sites along the Nakivubo Channelized Stream, Kampala, Uganda 
Makerere hill has two sources that merge at Kisekka market. The stream is $12.3 \mathrm{~km}$ long, $2.3 \mathrm{~km}$ of which is the Channel length of the upper and lower Nakivubo wetlands. The Nakivubo Channelized Stream is feed by six streams and divided into three sections namely; upstream (US01 - MD05) characterised by commercial establishments, midstream (MD05 - DS15) characterised by commercial and industrial establishment and downstream (DS15 and beyond), characterised by the Nakivubo wetland (Table 1). The study area is located $0^{\circ} 15^{\prime} \mathrm{N}$ and $32^{\circ} 30^{\prime} \mathrm{E}, 45 \mathrm{~km}$ north of the Equator and $8 \mathrm{~km}$ from Lake Victoria, with a total area of $190 \mathrm{~km}^{2}$ (Fig. 1). Samples were collected from the middle of the stream that flows and drains through Kampala City. Nakivubo swamp soils are characterised by alluvial and lacustrine sands, silt and clay. The alluvial soils in the upper layers are composed of semi-liquid organic material, reddish ferruginous loams and clays attributed to organic decomposition and runoff (Kansiime et al., 1995). Part of the industrial area soils are composed of shales, phillites and schists with a mixture of alluvial and lacustrine sand, silt and clay.

Water sampling and chemical analysis

A modified bulk sampler (Fig. 2) consisting of a polyethylene funnel with $20.8 \mathrm{~cm}$ opening, connected to a $5 \mathrm{~L}$ polyethylene conical flask was used in collection of rain water. The funnels and conical flasks were wrapped in an aluminium foil to avoid algal growth on the bulk precipitate and placed $1.5 \mathrm{~m}$ above the ground (Nyangababo et al, 2005a). The bulk precipitation collected in one-month was poured in one flask and mixed thoroughly to homogenize the precipitate from the five flasks. Duplicate samples of $500 \mathrm{~mL}$ were collected and transported to the laboratory in an ice box at $4{ }^{\circ} \mathrm{C}$ and the precipitate was first filtered through a $0.45 \mu \mathrm{m}$ filter and preserved with nitric acid. Heavy metal elements were then analyzed by direct aspiration of the sample solution into a Perkin-Elmer model 2380 Flame atomic absorption spectrophotometer. Stream water samples were collected over a one year period along the Nakivubo drainage system and Watindo Stream as described by Muwanga (1997). Watindo Stream was chosen to be outside the study area and therefore regarded as unpolluted. The samples were taken from the middle of the stream carefully to avoid contamination using sample bottles. Sampling bottles were washed with dilute nitric acid, rinsed

Table 1: Location and description of activities/establishment

\begin{tabular}{|c|c|c|c|c|}
\hline Site & Code & \multicolumn{2}{|c|}{ GPS readings } & Activity/ Establishment \\
\hline Upstream & & Lat. & Long. & \\
\hline $\begin{array}{l}\text { Agakhan high School } \\
\text { Bridge }\end{array}$ & US01 & 0.3221 & 32.5693 & $\begin{array}{l}\text { Car washing Bay, fish factory, gas/fuel station, residential, bus } \\
\text { parking yard, seepage from walls }\end{array}$ \\
\hline Kiseka market bridge & US03 & 0.3215 & 32.5716 & Car washing Bay, garage, commercial and seepage \\
\hline Fire brigade bridge & MS05 & 0.3129 & 32.5743 & $\begin{array}{l}\text { Commercial , recreational, vehicle traffic, Bus park, gas/petro } \\
\text { station, cement stores, Katwe metal works and fabrications and } \\
\text { seepage }\end{array}$ \\
\hline $\begin{array}{l}6^{\text {th }} \text { street bridge- } \\
\text { Mukwano } \\
\text { Downstream }\end{array}$ & MS09 & 0.3099 & 32.5891 & $\begin{array}{l}\text { Commercial, Oil storage in vicinity, vehicle traffic, gas/petro } \\
\text { station, seepage, industries }\end{array}$ \\
\hline Luzira Culvert & DS17 & 0.3188 & 32.6169 & Industries, cultivation, fishing, residential \\
\hline Tributaries & & & & \\
\hline Kayunga stream & MT07 & 0.3081 & 32.5782 & $\begin{array}{l}\text { Solid waste dump sites, horticulture, recreational, slum and } \\
\text { residential, vehicle traffic, gas/petro station }\end{array}$ \\
\hline Kitante stream & MT10 & 0.3099 & 32.5891 & $\begin{array}{l}\text { horticulture, recreational, residential and commercial, vehicle } \\
\text { traffic, gas/petro station }\end{array}$ \\
\hline Lugogo stream & MT13 & 0.3191 & 32.6011 & $\begin{array}{l}\text { Vehicle traffic, commercial, residential and industrial, electric } \\
\text { station, horticulture, carpentry works, pole treatment and seepage }\end{array}$ \\
\hline Kibira road stream & DT16 & 0.3142 & 32.611 & Battery, plastic and paper factory, industries and gas/petro station \\
\hline
\end{tabular}


with deionised water and again washed three times with the stream water before they were filled. For heavy metal analysis, a $500 \mathrm{~mL}$ bottle of linear polyethylene was used to collect water samples, filtered (using $0.45 \mu \mathrm{m}$ pore size) and three drops of concentrated nitric acid added for preservation. Also, $1 \mathrm{~L}$ bottle to collect water samples was used for determination of physico-chemical characteristics (total suspended solids and biological oxygen demand). All were stored in an ice box at $4^{\circ} \mathrm{C}$ and transported to Geology Laboratory at Makerere University and National Water and Sewerage Corporation central Laboratory at Bugolobi, respectively for analysis. Other physico-chemical characteristics such as dissolved oxygen, electrical conductivity, $\mathrm{pH}$, temperature and total dissolved solids were determined on site using potable meters. The elements were then analyzed by direct aspiration of the sample solution into a Perkin-Elmer model 2380 flame atomic absorption spectrophotometer (AAS) after calibration with suitable elemental standards at close intervals.

\section{Assessment of stream water contamination}

Total suspended solids (TSS); Wastewater TSS classification consists of three classes $(0-220 \mathrm{mg} / \mathrm{L})$ ranging from weak to strong $(<100 \mathrm{mg} / \mathrm{L})$ weak $(100-$ $220 \mathrm{mg} / \mathrm{L}$ ) medium and strong wastewater (> $220 \mathrm{mg} / \mathrm{L}$ ), Akan et al (2008).

Statistical analysis

Analysis of variance (ANOVA): ANOVA was employed to determine whether groups of variables have the same means on data that are continuous or normally distributed and with homogeneous variance. Additionally, it was employed to assess the relationship between heavy metal concentrations and their elemental interaction between sections of the stream.

Correlation analysis: Pearson correlation's correlation analysis was adopted to analyse and establish inter-metal relationship and physico-chemical characteristics of the stream water.

Cluster analysis (CA) and Factor analysis (FA): CA was performed using Minitab Release 14 or 15 to classify elements of different sources on the basis of their similarities using dendrogram and to identify relatively homogeneous groups of variables with similar properties. FA was employed on the variables that are correlated to isolate or determine specific factors that are associated with such groupings of metal concentration to establish their origin. The data was standardized to give a normal distribution with a mean of 0 and a variance of 1 . Sample means were standardized by subtracting the mean of their distribution and dividing by standard error (SE) or square root of the variance.

\section{RESULTS AND DISCUSSION}

Water chemical characteristics

Mean concentration of trace metals and physicochemical parameters are given in Table 2. The $\mathrm{pH}$ ranged from 6.30 to 9.83 for the Nakivubo Channelized

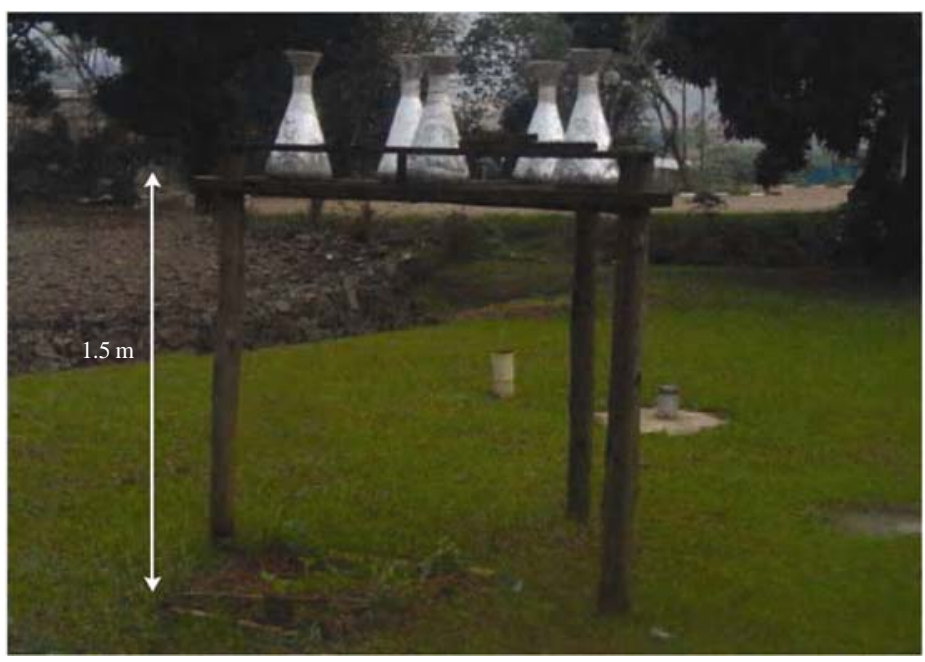

Fig. 2: Modified bulk sampler used in collection of rain water samples 
Stream suggesting a slightly acidic to alkaline $\mathrm{pH}$ which fell within the range of surface water under natural conditions (5.0 to 8.6), the value recorded at $6^{\text {th }}$ Street Bridge Mukwano fell well above the upper end of the range considered as normal, attributed to industrial wastewater outfall from Mukwano industreis. Dissolved oxygen (DO) ranged form 0.00 to $6.69 \mathrm{mg} / \mathrm{L}$ Nakivubo Stream, 0.0 to $7.39 \mathrm{mg} / \mathrm{L}$ tributaries, 0.0 to 4.4 $\mathrm{mg} / \mathrm{L}$, industrial discharge outfall and 0.40 to $5.48 \mathrm{mg} / \mathrm{L}$. Water was poorly aerated as indicated by very low dissolved oxygen in stream water which generally decreased downstream. WHO (2008) recommends $5.0 \mu \mathrm{m} / \mathrm{L}$ and above of DO but all stream water samples were bellow maximum permissible limit except Watindo Stream water which was relatively good. Dissolved oxygen below $5.0 \mathrm{mg} / \mathrm{L}$ may suggest aquatic contamination of such stream waters. Anoxic conditions are attributed to biochemical processes, oxidation of the substances, or decomposition of organic matter. Increased total dissolved solids (TDS) and biological oxygen demand (BOD) may suggest increased organic matter (OM) within the stream from industrial discharge, wastewater and effluents and ability of self-purification (Phiri et al, 2005; Akan., et al, 2007 and Akan et al, 2008). City Abattoir (105-395 $\mathrm{mg} / \mathrm{L})$, peacock paint factory (14-2150 mg/L) and Sadolin paint factory/Meat parker outlet (214-3725 $\mathrm{mg} / \mathrm{L}$ ) are the biggest contributors of total suspended solids (TSS) and hence registered the highest BOD (5.6-1304 mg/L, 16.3-1806 mg/L and 137.2-3192 mg/L, respectively) and EC. This phenomenon indicated industrial emission into the Nakivubo Channelized Stream as the major source of contaminants.

The mean value of BOD at sites US01, US04, MS05, MS09, DS15, DS17, DST16 and all industrial discharge outlets to Nakivubo Channel exceeded the National Environment Management Authority (NEMA) critical level of $50.0 \mathrm{mg} / \mathrm{L}$ maximum permissible limits in effluent and wastewater (Table 2). Also, the mean value of total suspended solids at sites US01, US02, US04, MS05, DS15, CT03 and all industrial discharge outlets exceed the maximum permissible limit of $100 \mu \mathrm{m} / \mathrm{L}$ in wastewater or effluents and is classified as strong wastewater at Peacock paint factory, Sadoline paint factory and NWSC plant (> 220.0 mg/L) outfall. Electric conductivity (EC) was highest at industrial discharge outfall wastewater followed by tributaries and ranged between 397.0 and $1884.0 \mu \mathrm{s} / \mathrm{cm}$ and 208.0 to $961.0 \mu \mathrm{s} /$ $\mathrm{cm}$, respectively whereas sadoline paint factory ranged between 208.0 and $961.0 \mu \mathrm{s} / \mathrm{cm}$ ). EC showed a trend of gradual increase downstream, suggesting increased dissolved elements/substances to Murchison Bay into Lake Victoria. These results are consistent with those of Kar et al., (2008). However, Total dissolved solids (TDS) were within National Electrical Manufacturers Association regulations for maximum permissible limit of discharge of wastewater and industrial effluents (1200 mg/L and 2000) (NEMA, 2006; WHO, 2008). Results of heavy metal concentration in stream water are shown in Table 3. Heavy metal concentrations in Nakivubo Channelized Stream water ranged from 44 \pm 18 to $129 \pm 70 \mu \mathrm{m} / \mathrm{L} \mathrm{Pb} ; 3 \pm 1$ to $9 \pm 4 \mu \mathrm{m} / \mathrm{L} \mathrm{Cd} ; 8 \pm 2$ to $44 \pm 35 \mu \mathrm{m} / \mathrm{L} \mathrm{Cu} ; 26 \pm 6$ to $59 \pm 9 \mu \mathrm{m} / \mathrm{L} \mathrm{Zn;} 505 \pm 495$ to $1035 \pm 65 \mu \mathrm{m} / \mathrm{L} \mathrm{Mn}$ and $300 \pm 200$ to $1450 \pm 550 \mu \mathrm{m} /$ L Fe. Stream water samples at Kiseka Market Bridge were the most contaminated by $\mathrm{Pb}$, followed by the Luzira Culvert along the Nakivubo Channelized Stream. Generally, Pb concentration increased downstream but with the highest contributions from industrial discharge outfall.

The concentration of $\mathrm{Pb}$ exceeded the WHO (2008) for drinking water at most of the sites and NEMA, (2006) maximum permissible limit of discharge of wastewater into the environment $(100 \mu \mathrm{m} / \mathrm{L})$ at Kiseka Market, Kibira road tributary and Sadoline paint factory, However, $\mathrm{Pb}$ heavy metal concentrations at all sites exceeded $25 \mu \mathrm{m} / \mathrm{L}$ criterion for the protection of aquatic life. Total heavy metal content in stream waters along the tributaries to Nakivubo Channel ranged from $63 \pm$ 24 to $106 \pm 27 \mu \mathrm{m} / \mathrm{L} \mathrm{Pb} 3 \pm 2$ to $6 \pm 2 \mu \mathrm{m} / \mathrm{L} \mathrm{Cd} ; 2 \pm 4$ to $8 \pm 4 \mu \mathrm{m} / \mathrm{L} \mathrm{Cu}$ and $51 \pm 11$ to $144 \pm 24 \mu \mathrm{m} / \mathrm{L} \mathrm{Zn}$. Stream water along Kibira Stream tributary was the most contaminated with $\mathrm{Zn}$, followed by Kitante stream and Lugogo. Lugogo stream water had the highest concentration of Cd $(13 \pm 6 \mu \mathrm{m} / \mathrm{L})$ and $\mathrm{Cu}(18 \pm 12 \mu \mathrm{m} /$ $\mathrm{L}$ ) followed by Kibira and Kayunga streams Cd (64 \pm $20 \mu \mathrm{m} / \mathrm{L})$ and Kitante $\mathrm{Cu}(16 \pm 7 \mu \mathrm{m} / \mathrm{L})$. The concentration of Cd exceeded WHO (2008) maximum permissible limit of $3 \mu \mathrm{m} / \mathrm{L}$ in wastewater. Heavy metal contents in stream waters at industrial discharge outlets range from $69 \pm 25$ to $113 \pm 31 \mu \mathrm{m} / \mathrm{L} \mathrm{Pb} ; 4 \pm 2$ to $12 \pm 5$ $\mu \mathrm{m} / \mathrm{L} \mathrm{Cd} ; 8 \pm 3$ to $18 \pm 4 \mu \mathrm{m} / \mathrm{L} \mathrm{Cu} ; 51 \pm 11$ to $144 \pm 25 \mu \mathrm{m} /$ $\mathrm{L} Z \mathrm{Zn} ; 165 \pm 35$ to $2400 \pm 700 \mu \mathrm{m} / \mathrm{L}$ and $600 \pm 100$ to 3050 $\pm 550 \mu \mathrm{m} / \mathrm{L}$ Fe. The range obtained from discharge outlets were within the NEMA standards for discharge of effluents and wastewater critical levels for $\mathrm{Cd}, \mathrm{Cu}$ and $\mathrm{Zn}$, except $\mathrm{Pb}$ which exceeds the limit of $100 \mu \mathrm{m} / \mathrm{L}$ as the maximum contaminant level at Sadoline paint 





factory discharge outlet, Kisekka market and Kibira Road Stream which is a surrogate discharge outlet for Uganda batteries Limited factory and Nice House of plastics factory (Table 3). Heavy metal concentration in rain for $\mathrm{Pb}(13 \mu \mathrm{m} / \mathrm{L}$ and $33 \mu \mathrm{m} / \mathrm{L})$ was above water quality criterion value set for domestic supplies at WHO standards whereas, the rest were below the maximum permissible limits. The levels of concentrations of lead in rain water were far below that in stream water. Elemental concentrations of $\mathrm{Pb}, \mathrm{Cd}$, $\mathrm{Cu}$ and $\mathrm{Zn}$ were below the concentrations in effluents observed by Nabulo et al., (2008) except Cd at Peacock paint factory effluent which was in the same order of magnitude. However heavy metal concentrations in stream water along the Nakivubo Channel were in the same order of magnitude with those observed by Muwanga and Balifaijo, (2006).

Manganese concentrations exceeded the limit of $1000 \mu \mathrm{m} / \mathrm{L}$ as the maximum permissible limit of wastewater discharge into the environment at
Mukwano industries, Peacock paint factory outfall and Kayunga tributary inflows leading to its accumulation downstream. The concentration of heavy metals along Watindo Stream ranged from $50 \pm$ 18 to $106 \pm 47 \mu \mathrm{m} / \mathrm{L} \mathrm{Pb} ; 2 \pm 1$ to $5 \pm 2 \mu \mathrm{m} / \mathrm{L} \mathrm{Cd} ; 5 \pm 2$ to $14 \pm 6 \mu \mathrm{m} / \mathrm{L} \mathrm{Cu} ; 20 \pm 4$ to $241 \pm 5 \mu \mathrm{m} / \mathrm{L} \mathrm{Zn;} 155 \pm 145$ to $165 \pm 135 \mu \mathrm{m} / \mathrm{L} \mathrm{Mn}$ and $4050 \pm 250$ to $4600 \pm 1000 \mu \mathrm{m} /$ $\mathrm{L}$ Fe (Table 3). The mean Cd concentration in stream water at site CT01 and CT02 exceeded WHO (2008) maximum permissible limit for drinking water. But $\mathrm{Pb}$, $\mathrm{Cu}, \mathrm{Mn}$ and Fe concentrations in water of several magnitudes higher than surface water standards (Table $3)$. This phenomenon is of common occurrence in most populated urban areas close to industrial establishments (Mohiuddin et al., 2010).

Analysis of variance: The two-way ANOVA in table 4a-b indicate that sites show no significant effect on variation between groups of means of the heavy metals at deferent stream sections (Table 4a). However, the mean heavy metal concentrations of elements within

Table 3: Mean values and SE of trace metal concentrations in water at different sites along Nakivubo Channelized Stream and its Tributaries, Industrial effluent, rain water and Watindo Stream $(n=16)$

\begin{tabular}{|c|c|c|c|c|c|c|}
\hline \multirow[b]{2}{*}{ Sites } & \multicolumn{6}{|c|}{ Heavy metals $(\mu \mathrm{g} / \mathrm{L})$} \\
\hline & $\mathrm{Pb}$ & $\mathrm{Cd}$ & $\mathrm{Cu}$ & $\mathrm{Zn}$ & Mn & $\mathrm{Fe}$ \\
\hline \multicolumn{7}{|l|}{ Nakivubo stream } \\
\hline US01 & $44 \pm 18$ & $4 \pm 2$ & $9 \pm 30$ & $26 \pm 6$ & $600 \pm 500$ & $300 \pm 300$ \\
\hline US02 & $45 \pm 20$ & $4 \pm 2$ & $12 \pm 6.0$ & $26 \pm 5$ & $535 \pm 465$ & $500 \pm 100$ \\
\hline US03 & $129 \pm 70$ & $9 \pm 4$ & $44 \pm 35$ & $34 \pm 7$ & $505 \pm 495$ & $300 \pm 200$ \\
\hline US04 & $3 \pm 9.0$ & $3 \pm 1$ & $8 \pm 2.0$ & $46 \pm 7$ & $685 \pm 215$ & $900 \pm 400$ \\
\hline MS05 & $53 \pm 26$ & $5 \pm 2$ & $27 \pm 20$ & $59 \pm 9$ & $955 \pm 145$ & $1250 \pm 350$ \\
\hline MS09 & $63 \pm 24$ & $4 \pm 2$ & $21 \pm 12$ & $37 \pm 6$ & $1000 \pm 300$ & $1200 \pm 100$ \\
\hline DS15 & $81 \pm 23$ & $6 \pm 4$ & $15 \pm 6$ & $51 \pm 8$ & $675 \pm 125$ & $1050 \pm 350$ \\
\hline DS17 & $88 \pm 24$ & $4 \pm 2$ & $13 \pm 6$ & $33 \pm 5$ & $1035 \pm 650$ & $1450 \pm 550$ \\
\hline \multicolumn{7}{|l|}{ Tributaries } \\
\hline MT07 & $64 \pm 20$ & $4 \pm 2$ & $6 \pm 2$ & $31 \pm 5$ & $1915 \pm 185$ & $2000 \pm 700$ \\
\hline MTS10 & $63 \pm 24$ & $3 \pm 2$ & $16 \pm 7$ & $49 \pm 14$ & $155 \pm 145$ & $250 \pm 250$ \\
\hline MT13 & $75 \pm 30$ & $3 \pm 6$ & $18 \pm 12$ & $32 \pm 6$ & $475 \pm 425$ & $1000 \pm 200$ \\
\hline DT16 & $106 \pm 27$ & $4 \pm 2$ & $9 \pm 3$ & $157 \pm 34$ & $475 \pm 25$ & $1250 \pm 450$ \\
\hline \multicolumn{7}{|l|}{ Industrial Effluents } \\
\hline MD08 & $100 \pm 34$ & $4 \pm 2$ & $25 \pm 0.008$ & $65 \pm 18$ & $1415 \pm 1384$ & $900 \pm 800$ \\
\hline MDS11 & $69 \pm 25$ & $12 \pm 5$ & $8 \pm 0.003$ & $51 \pm 11$ & $2400 \pm 700$ & $800 \pm 700$ \\
\hline MD12 & $113 \pm 31$ & $6 \pm 2$ & $18 \pm 0.004$ & $144 \pm 24$ & $670 \pm 30$ & $3050 \pm 550$ \\
\hline MD14 & $93 \pm 37$ & $3 \pm 2$ & $15 \pm 0.003$ & $92 \pm 15$ & $165 \pm 35$ & $600 \pm 100$ \\
\hline \multicolumn{7}{|l|}{ Watindo stream } \\
\hline СТ01 & $106 \pm 47$ & $4 \pm 2$ & $14 \pm 0.006$ & $20 \pm 4$ & $160 \pm 140$ & $4050 \pm 250$ \\
\hline СТ02 & $75 \pm 31$ & $5 \pm 2$ & $5 \pm 5$ & $24 \pm 5$ & $155 \pm 145$ & $4300 \pm 400$ \\
\hline СТ03 & $50 \pm 18$ & $2 \pm 1$ & $11 \pm 6$ & $22 \pm 4$ & $165 \pm 135$ & $4600 \pm 100$ \\
\hline \multicolumn{7}{|l|}{ Rain water } \\
\hline Rw1n & $13 \pm 9$ & $2 \pm 1$ & $14 \pm 7$ & $18 \pm 5$ & $50 \pm 50$ & $200 \pm 200$ \\
\hline Rw2w & $33 \pm 19$ & $3 \pm 1$ & $25 \pm 20$ & $21 \pm 3$ & $10 \pm 10$ & $100 \pm 0$ \\
\hline **WHO, 2008 & 10 & 3 & 2000 & 3000 & 100 & 300 \\
\hline * NEMA, 2006 & 100 & 100 & 1000 & 5000 & 1000 & \\
\hline ***surface water & 0.015 & - & 1.3 & - & 0.05 & 0.3 \\
\hline
\end{tabular}


sites differed significantly at different stream sections; upstream $\left(\mathrm{F}_{3,15}=27.33, \mathrm{P}<0.001\right)$; midstream $\left(\mathrm{F}_{1,5}\right.$ $=1828.280, \mathrm{P}<0.001)$ and downstream $\left(\mathrm{F}_{1,5}=51.620, \mathrm{P}<\right.$ $0.001)$, at $\mathrm{P}=0.05$.Sections of the stream have significant effect on the mean heavy metal concentrations $\left(\mathrm{F}_{2,30}=\right.$ 13.3, $\mathrm{P}<0.001$ ), Table 4b. However, there was also a significant difference among heavy metal concentrations between sections of the stream $\left(\mathrm{F}_{2,30}=\right.$ 139.26, $\mathrm{P}<0.001)$. The effects of interaction between sections and mean heavy metal concentration was significant $\left(\mathrm{F}_{2,30}=5.79, \mathrm{P}<0.001\right)$ suggesting a transport phenomenon or mobility of heavy metals.

Correlation analysis: Pearson correlation coefficients for the data were evaluated to determine the level of inter-metal association and the values are shown in Table 5. Elemental pairs $\mathrm{Pb} / \mathrm{Cd}(\mathrm{r}=0.56)$; $\mathrm{Pb} / \mathrm{Zn}(\mathrm{r}=$ $0.50) ; \mathrm{Cd} / \mathrm{Mn}(\mathrm{r}=0.52)$ and $\mathrm{Mn} / \mathrm{Fe}(\mathrm{r}=0.56)$ were significantly correlated with each other, suggesting that each paired elements have identical source or chemical phenomena, whereas the rest of the elemental pairs are not correlated with each other. The association of Mn with Fe in stream water may strengthen terrigenous sources and/or geo-chemistry. Metals show correlation with the physico-chemical characteristics. Pairs $\mathrm{Pb} /$ TDS, Pb/EC, Cd/EC, Zn/EC, Zn/BOD and Mn/EC are positively correlated with each other and Zn/DO and $\mathrm{Fe} / \mathrm{DO}$ were negatively correlated, suggesting their Physico-chemical associations, whereas the rest of the metals and physico-chemical parameters are not correlated. Positive correlation of Cd/EC elemental pair was consistent with that of Kar et al., (2008). Table 5 also shows that pairs BOD/TDS, BOD/TSS, DO/EC, TDS/DO, EC/TDS and TSS/TDS were significantly correlated with each other, whereas the rest of the pairs are not correlated. Very high BOD and very low DO in the stream water suggest pollution by organic matter and decomposition as a self purification mechanism. This phenomenon results into a reducing condition in organic rich stream water. These results are in line with those done by Igbinosa and Okoh, (2009). The development of reducing condition in stream water promotes the reduction of iron and manganese hydroxides (Linnik and Zubenko, 2000). Under slightly acidic to alkaline condition, Cd specifically adsorbed proportion is high in solid phase and $\mathrm{Pb}$ may occur bonded to poorly crystalline oxides (Fergusson 1990). The $\mathrm{pH}$ values (slightly acidic to alkaline), may limit the degree of desorption of heavy metals into solution and can promote co-precipitation except $\mathrm{Pb}$ at $\mathrm{pH}>6$ the solubility is governed by soluble organic ligands under reducing conditions (Muwanga, 1997). Contaminants released to flow in restricted water bodies at the mixing event can promote co-precipitation (Anazawa et al., 2004).

Cluster analysis and factor analysis: Cluster analysis was performed on the data using Average linkage and correlation coefficient distance. Results of cluster analysis are shown in Fig. 3. Four groups of elemental associations with eigenvalue $>1$ were

Table 4a: Two-way ANOVA results for sites and heavy metal concentration variables (Dependant variables were log-normal transformed)

\begin{tabular}{llccrrr}
\hline Stream sections & Source of Variation & DF & SS & MS & F & 0.920 \\
\hline \multirow{2}{*}{ Upstream } & Sites & 3 & 0.003 & 0.001 & 0.454 \\
& Metal content & 5 & 0.162 & 0.032 & 27.330 & 0.000 \\
Midstream & Sites & 1 & 0.000 & 0.000 & 0.180 & 0.689 \\
& Metal content & 5 & 0.255 & 0.051 & 1828.280 \\
Downstream & Sites & 1 & 0.002 & 0.002 & 2.210 & 0.197 \\
& Metal content & 5 & 0.238 & 0.048 & 51.620 \\
\hline
\end{tabular}

DF-degree of freedom; F-factor mean square SS- Sum of squares; MS- Mean square; $\mathrm{P}=0.05$

Table 4b: Two-way ANOVA results for stream sections and mean heavy metal concentration variables (dependant variables were log-normal transformed)

\begin{tabular}{|c|c|c|c|c|c|}
\hline Source of Variation & $\mathrm{DF}$ & SS & MS & $\mathrm{F}$ & $\mathrm{P}$ \\
\hline Sections & 2 & 0.000 & 0.01232 & 13.3 & 0.000 \\
\hline Metal content & 5 & 1.000 & 0.12904 & 139.26 & 0.000 \\
\hline Sections*Metal & 10 & 0.000 & 0.00536 & 5.79 & 0.000 \\
\hline
\end{tabular}

SS- Sum of squares; MS- Mean square; $\mathrm{P}=0.05$ 
extracted in the analysis. Heavy metal elements were fused into clusters because of their relative elemental concentrations at each site and their similarity coefficients. Group I contains $\mathrm{Pb}$ and $\mathrm{Cu}$ while group II consists of $\mathrm{Cd}$, Mn and Fe. Group III contains Zn as well as BOD, TDS, EC, TSS and stream water $\mathrm{pH}$.

Biplot of sites and elemental concentrations suggest that Kibira Road stream is a source of $\mathrm{Zn}$, $\mathrm{Pb}$ and copper, whereas Mukwano industries is a point source of $\mathrm{Zn}$ and $\mathrm{Pb}$ (Fig. 3). Sadoline paint factory was the point source of $\mathrm{Pb}$ and $\mathrm{Zn}$, whereas NWSC is the point source of $\mathrm{Cu}, \mathrm{Zn}$ and $\mathrm{Pb}$. Inflows of Kayunga Stream into the Nakivubo Channelized Stream comes with $\mathrm{Mn}$ and $\mathrm{Cd}$. The lengths of the arrow for $\mathrm{Pb}$ and $\mathrm{Zn}$ suggest that NWSC were the highest source, Peacock paint factory for Fe, Kayunga and Lugogo streams for $\mathrm{Mn}$ and $\mathrm{Cd}$.

The firs factor accounts for $35.7 \%$ of the total variance and contains $\mathrm{Zn}$ and $\mathrm{Fe}$ as well as water $\mathrm{pH}$, total dissolved solids, TSS, electrical conductivity and BOD, with high variable loadings on this factor (Table 6) and corresponds to group III of the cluster analysis. Organic factor may indicate point sources such as municipal and industrial effluents and adsorption by TDS as well as flocculation or co-precipitation which is $\mathrm{pH}$ controlled (Balachandran et al., 2005; Karbassi et al., 2007; Abdel-Ghani and Elchaghaby, 2007; AbdelGhani et al., 2009) TDS and TSS seems to play a major role in the adsorption of heavy metals in stream water rich with organic matter. These phenomena remove heavy metals rapidly and render it free of contamination under varying dissolved salts.

The second factor accounts for $19.9 \%$ of the variance and contains $\mathrm{Cd}$, $\mathrm{Mn}$ and Fe with high variable loadings on this factor which corresponds to group II of the cluster analysis. This indicates co-precipitation of $\mathrm{Cd}$ with $\mathrm{Mn}$ and Fe oxides/ hydroxides. The third factor accounts for $16.8 \%$ of the variance and contains $\mathrm{Pb}, \mathrm{Cd}$ and $\mathrm{Cu}$ with high variable loadings on this factor and corresponds to group I of the cluster analysis. This factor is considered to represent anthropogenic toxic pollutants from metal works and fabrications, vehicular and industrial emissions. Distribution of Zn between different factors 1 and 2 may suggest dual sources whereas $\mathrm{pH}$ indicates its influence as a controlling factor on heavy metal co-precipitation.

Table 5: Pearson correlation coefficient matrix (r) for mean heavy metal contents and physicochemical characteristics in Nakivubo Channelized Stream water $(\mathrm{n}=16)$

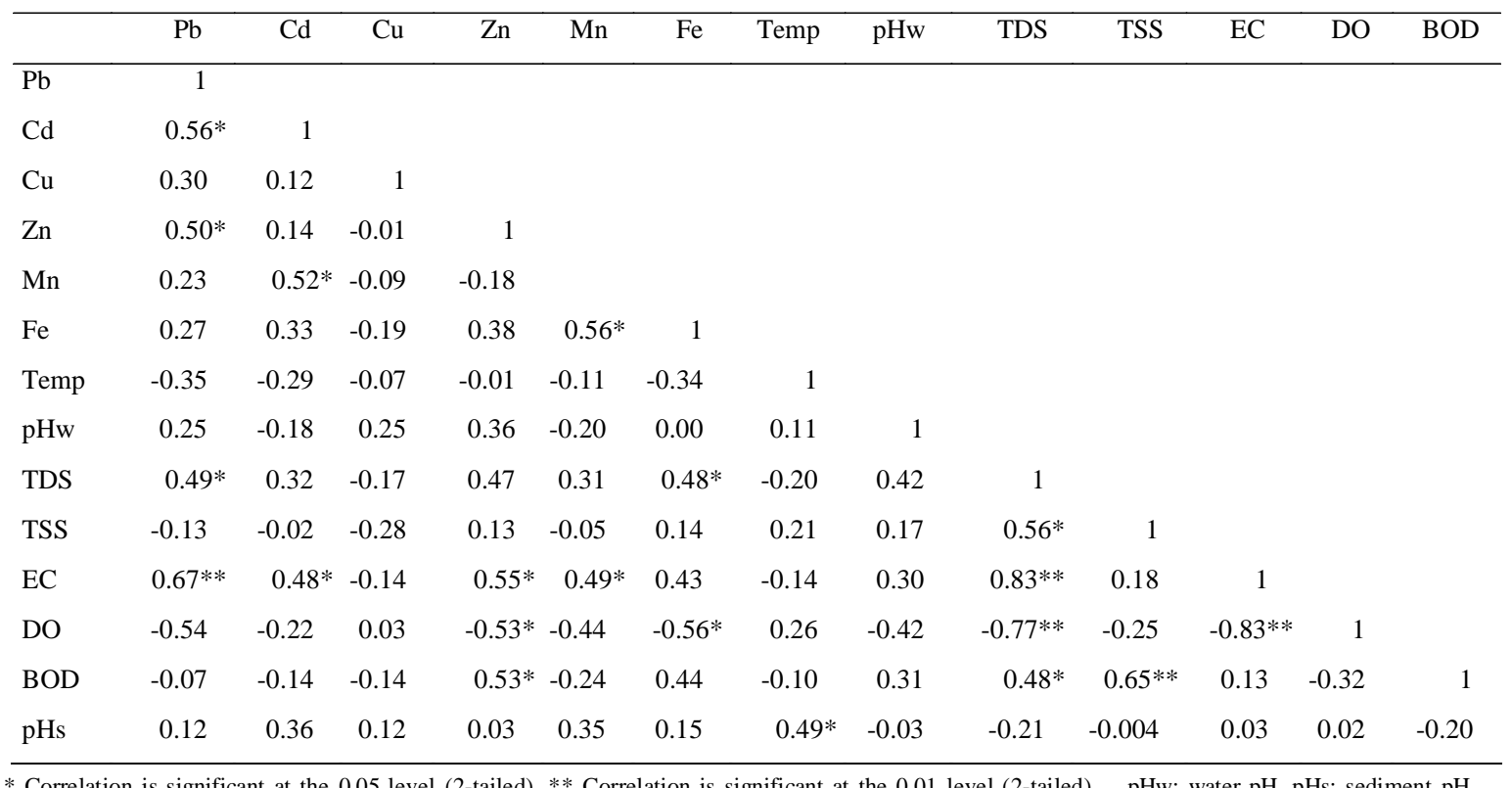

* Correlation is significant at the 0.05 level (2-tailed), ** Correlation is significant at the 0.01 level (2-tailed) $\mathrm{pHw}$; water $\mathrm{pH}$, pHs; sediment $\mathrm{pH}$ 


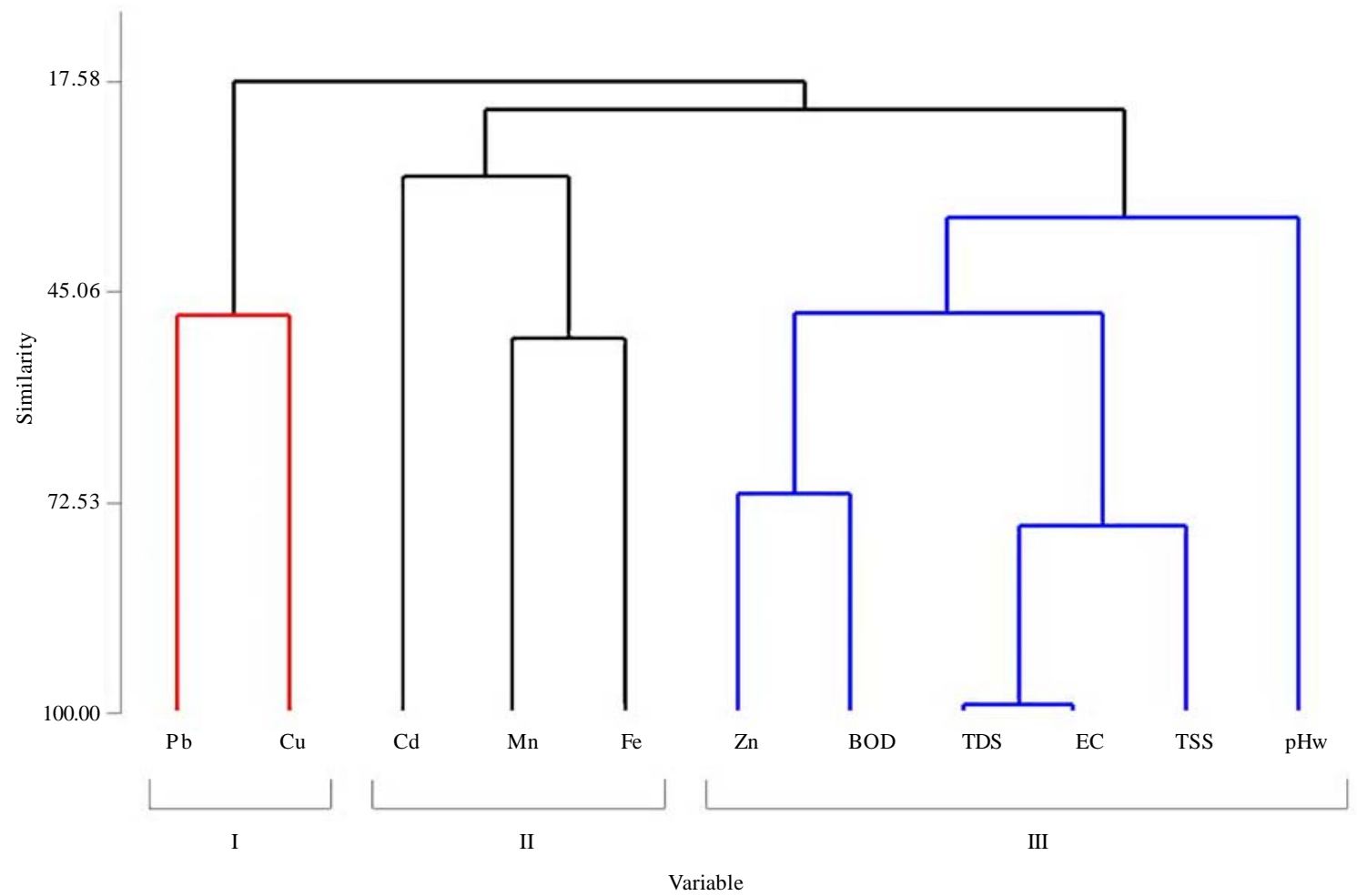

Fig. 3: Dendrogram of elemental concentrations and physico-chemical parameters of Nakivubo Channelized stream water and industrial discharge effluents $(n=16)$
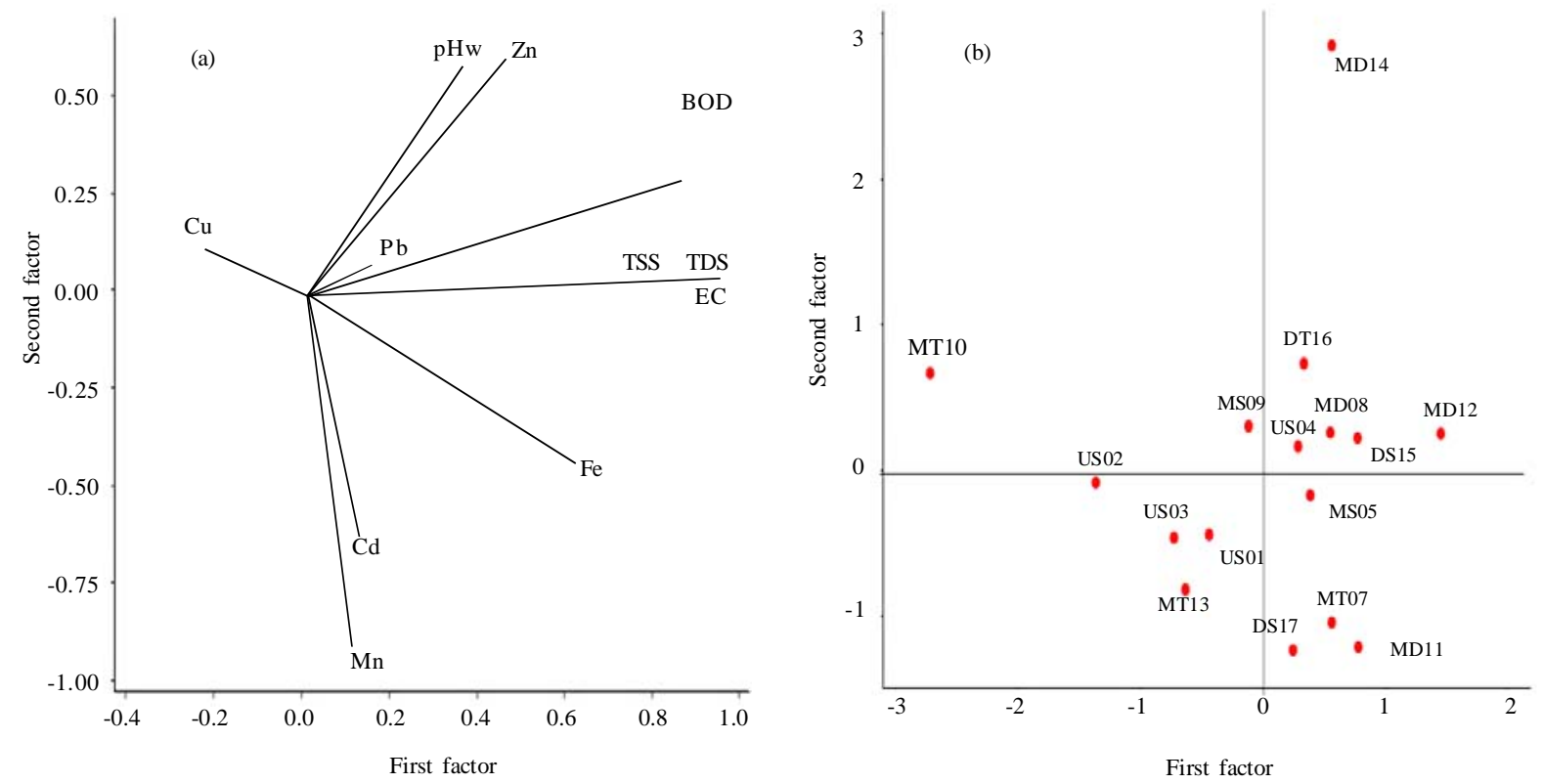

Fig. 4: Biplot of elemental concentrations (a) and sites (b) of stream water 
Table 6: Rotated factor loadings and communalities of elements and physico-chemical characteristics in stream water samples $(n=16)$

\begin{tabular}{lrrrc}
\hline Variable & Factor 1 & Factor 2 & Factor 3 & Communality \\
\hline $\mathrm{Pb}$ & 0.152 & 0.075 & 0.865 & 0.777 \\
$\mathrm{Cd}$ & 0.121 & -0.613 & 0.525 & 0.666 \\
$\mathrm{Cu}$ & -0.237 & 0.122 & 0.791 & 0.697 \\
$\mathrm{Zn}$ & 0.451 & 0.608 & 0.211 & 0.618 \\
$\mathrm{Mn}$ & 0.102 & -0.896 & -0.044 & 0.815 \\
$\mathrm{Fe}$ & 0.614 & -0.428 & 0.077 & 0.567 \\
$\mathrm{pH}-\mathrm{w}$ & 0.352 & 0.589 & 0.266 & 0.542 \\
$\mathrm{TDS}$ & 0.924 & 0.041 & 0.068 & 0.859 \\
$\mathrm{TSS}$ & 0.799 & 0.036 & -0.231 & 0.693 \\
EC & 0.944 & 0.041 & 0.27 & 0.909 \\
BOD & 0.858 & 0.294 & -0.045 & 0.824 \\
Variance & 3.9269 & 2.1912 & 1.8494 & 7.9675 \\
\% Var. & 0.357 & 0.199 & 0.168 & 0.724 \\
\hline
\end{tabular}

\section{CONCLUSION}

The Nakivubo Stream water is stripped of heavy metal contaminants. Because of this, the quality of the Nakivubo aquatic ecosystem is improved. However, high anoxic conditions attributed to biochemical processes and decomposition of organic matter as a purification mechanism (organic matter pollution) poses a threat to aquatic life. The greatest threat in Nakivubo Channelized Stream water would be posed by $\mathrm{Pb}$ and $\mathrm{Cd}$ which almost always occur as mobile elements in water under neutral to alkaline conditions but are always rapidly removed. Flocculation and coprecipitation of $\mathrm{Mn}$ and Fe hydroxides, water $\mathrm{pH}$ and TDS could be the major mechanism explaining the rapid removal of $\mathrm{Pb}$ and $\mathrm{Cd}$ to bottom sediments. The levels of dissolved oxygen were below the maximum permissible limit, while the mean biological oxygen demand was above the maximum permissible limit. FA results reveal two sources of pollutants as explained by three factors (72.40\%); (i) mixed origin or chemical phenomena of industrial and vehicular emissions, and (ii) dual origin of $\mathrm{Zn}$ (vehicular, commercial establishment and industrial). Atmospheric deposition of heavy metals especially $\mathrm{Pb}$ in rain is apparent and may be attributed to vehicular emissions.

\section{ACKNOWLEDGEMENTS}

The authors are thankful to Kampala International University for the financial support in form of PhD research project and Department of Geology, Faculty of science, Makerere University, for geochemical analyses.

\section{REFERENCES}

Abdel-Ghani, N. T.; Elchaghaby, G. A., (2007). Influence of operating conditions on the removal of $\mathrm{Cu}, \mathrm{Zn}, \mathrm{Cd}$ and $\mathrm{Pb}$ ions from wastewater by adsorption. Int. J. Environ. Sci. Tech., 4 (4), 451-456 (6 pages).

Abdel-Ghani, N. T.; Hegazy, A. K.; El-Chaghaby, G. A., (2009). Typha domingensis leaf powder for decontamination of aluminium, iron, zinc and lead: Biosorption kinetics and equilibrium modeling. Int. J. Environ. Sci. Tech., 6 (2), 243248 (6 pages).

Akan, J. C.; Abdulrahman, F. I.; Dimari, G, A.; Ogugbuaja, V. O., (2008). Physicochemical determination of pollutants in wastewater and Vegetable samples along the Jakara Wastewater Channelin Kano Metropolis Kano State, Nigeria. Europ. J. Sci.Res., 23 (1), 122-133 (12 pages).

Akan, J. C.; Abdulrahman, F. I.; Ayodele, J. T.; Ogugbuaja, V.O., (2007). Studies on the effect of Municipal waste and Industrial effluents on the Pollutant level of River Challawa, Kano State, Nigeria. Res. J. Appl. Sci., 2 (4), 530-535 (6 pages).

Al-Juboury, A. I., (2009). Natural Pollution By Some Heavy Metals in the Tigris River, Northern Iraq. Int. J. Environ. Res., 3 (2), 189-198 (10 pages).

Anderson, D., (2003). Introduction to heavy metal monitoring. UK.

Anazawa, K.; Kaida, Y.; Tomiyasu, T.; Sakamoto, H., (2004). Heavy metal distribution in river waters and sediments around a ''Firely Village', Shikoku, Japan: Application of Multivariate analysis. Japan Soc. Anal. Chem., 20 (1), 79-84 (6 pages).

Awofolu, O. R.; Mbolekwa, Z.; Mtshemla, V.; Fatoki, O. S., (2005). Levels of heavy metals in water and sediments from Tyume River and its effects on an irrigated farmland. Water SA. 31 (1), 87-94 (8 pages).

Babel, S.; Opiso, E. M., (2007). Removal of Cr from synthetic wastewater by sorption into volcanic ash soil. Int. J. Environ. Sci. Tech., 4 (1), 99-107 (9 pages).

Balachandran, K. K.; Lalu Raj, C. M.; Nair, M.; Joseph, T.; Sheeba, P.; Venugopal, P., (2005). Heavy metal accumulation in a flow restricted, tropical estuary. Estuar. Coast. Shelf Sci., 65 (1-2), 361-370 (10 pages).

Campbell, L. M., (2001). Mercury in Lake Victoria (East Africa): Another emerging issue for a Beleaguered Lake? PhD, Thesis. Waterloo, Ontario, Canada.

Fergusson, J. E., (1990). The heavy elements: Chemistry, environmental impact and health effects. Pergamon Press, Oxiford, 614.

Igbinosa, E. O.; Okoh, A. I., (2009). Impact of discharge wastewater effluents on the phsico-chemical qualities of a receiving water shade in typical rural community. Int. J. Environ. Sci. Tech. 6 (2), 175-182 (8 pages).

Igwe, J. Ch.; Abia, A. A.; Ibe, Ch. A., (2008). Adsorption kinetics and intraparticulate diffusivities. Int. J. Environ. Sci. Tech., 5 (1), 83-92 (10 pages).

Kansiime, F.; Kateyo ,E.; Okot-okumu, J., (1995). Effects of pollution on Inner Murchison bay (Lake VictoriaUganda) on the distribution and abundance of plankton. A 
report of Makerere Institute of Environment and Natural Resources.

Kar, D.; Sur, P.; Mandal, S. K.; Saha, T.; Kole, R. K., (2008). Assessment of heavy metal pollution in surface water. Int. J. Environ. Sci. Tech., 5 (1), 119-124 (6 pages).

Karbassi, A. R.; Nouri, J.; Ayaz, G. O., (2007). Flocculation of trace metals during mixing of Talar river water with Caspian Seawater. Int. J. Environ. Res., 1 (1), 66-73 (8 pages).

Linnik, P. M.; Zubenko, I. B., (2000). Role of bottom sediments in the secondary pollution of aquatic environments by heavy metal compounds. Lakes and Reservoirs. Res. Manag., 5 (1), 11-21 (10 pages).

Lomniczi, I.; Boemo, A.; Musso, H., (2007). Location and characterisation of pollution sites by principal component analysis of trace contaminants in a slightly polluted seasonal river: A case study of the Arenales River (Salta, Argentina). Water SA., 33 (4), 479-485 (7 pages).

Lwanga, M. S.; Kansiime, F.; Denny, P.; Scullion, J., (2003). Heavy metals in Lake George, Uganda with relation to metal concentrations in tissues of common fish species. Hydrobiology, 499 (1-3), 83-93 (11 pages).

Muwanga, A., (1997). Environmental impacts of copper mining at Kilembe, Uganda: A geochemical investigation of heavy metal pollution of drainage waters, stream, sediments and soils in the Kilembe valley in relation to mine waste disposal. Ph.D. Dissertation, Universitat Braunschweig, Germany.

Muwanga, M.; Balifaijo, E., (2006). Impact of industrial activities on heavy metal loading and their physiochemical effects on wetlands of Lake Victoria Basin (Uganda). African J. Sci. Tech., 7 (1), 51-63 (13 pages).

Mohiuddin, K. M.; Zakir, H. M.; Otomo, K.; Sharmin, S.; Shikazono, N., (2010). Geochemical distribution of trace metal pollutants in water and sediments of downstream of an urban river. Int. J. Environ. Sci. Tech., 7 (1), 17-28 (12 pages).

Mwiganga, M.; Kansiime F., (2005). Impact of Mpererwe landfill in Kampala Uganda, on the surrounding environment. Phys. Chem. Earth., 38 (11-16), 91-95 (5 pages).
Nabulo, G.; Oryem Origa, H.; Nasinyama, G. W.; Cole, D., (2008). Assessment of $\mathrm{Zn}, \mathrm{Cu}, \mathrm{Pb}$ and $\mathrm{Ni}$ contamination in wetland soils and plants in the Lake Victoria basin. Int. J. Environ. Sci. Tech., 5 (1), 65-74 (10 pages).

NEMA (2006). National Environment Management Authority., State of environment report for Uganda.

Nyangababo, J. T.; Henry, I.; Omutunge, E., (2005a). Heavy metal contamination in plants, sediments and air precipitation of Katonga, Simiyu and Nyando wetlands of Lake Victoria basin, East Africa. Bull Environ. Contam. Toxicol., 75 (1), 189-196 (8 pages).

Nyangababo, J. T.; Henry, E.; Omutange, E., (2005b). Lead, cadmium, copper, manganese and zinc in wetland waters of Victoria lake basin, East Africa. Bull. Environ. Contam. Toxicol., 74 (5), 1003-1010 (8 pages).

Phiri, O.; Mumba, P.; Moyo, B. H; Kadewa, W., (2005). Assessment of the impact of industrial effluent on water quality of receiving rivers in urban areas of Malawi. Int. J. Environ. Sci. Tech., 2 (3), 237-244 (8 pages).

Samarghandi, M. R.; Nouri, J.; Mesdaghinia, A. R.; Mahvi, A. H.; Nasseri, S.; Vaezi, F., (2007). Efficiency removal of phenol, lead and cadmium by means of $\mathrm{UV} / \mathrm{TiO}_{2} / \mathrm{H}_{2} \mathrm{O}_{2}$ processes. Int. J. Environ. Sci. Tech., 4 (1), 19-25 (7 pages).

Sentongo, J., (1998). Assessment of pollution to Lake Victoria by industrial and municipal activities around Lake Victoria in Uganda., M.Sc. Thesis., Makerere University, Uganda.

Srivastava, A.; Gupta, S.; Jain, V. K., (2008). Source apportionment of suspended particulate matter in coarse and fine size ranges over Delhi. Aerosol Air Qual. Res., 8 (2), 188 - 200 (13 pages).

Wasswa, J., (1997). Determination of levels of pollutants within sediments in water channels from industries in selected parts of Lake Victoria. M.Sc., Thesis, Makerere University, Uganda.

WHO., (2008). Guidelines for drinking - water Quality $3^{\text {rd. }}$ Edition incorporating the first and second agenda volume 1 Recommendations, World Health Organizations Geneva.

\section{AUTHOR (S) BIOSKETCHES}

Sekabira, K., Ph.D. Scholar, Department of Environment, Faculty of Science and Engineering, Kampala International University, P. O. Box 20000, Kampala, Uganda; Email: ssekaba@gmail.com

Oryem Origa, H., Ph.D., Professor, Department of Botany, Faculty of Science, Makerere University, P. O. Box 7062, Kampala, Uganda. Email: horyem_origa@botany.mak.ac.ug

Basamba, T. A., Ph.D., Department of Soil Science, Faculty of Agriculture, Makerere University, P. O. Box 7062, Kampala, Uganda. Email: ateenyitwaha@hotmail.com

Mutumba, G., Ph.D., Assistant Professor, Department of Botany, Faculty of Science, Makerere University, P. O. Box 7062, Kampala, Uganda. Email: gmutumba@botany.mak.ac.ug

Kakudidi, E., Ph.D., Department of Botany, Faculty of Science, Makerere University, P. O. Box 7062, Kampala, Uganda. Email: ekakudidi@sci.mak.ac.ug

How to cite this article: (Harvard style)

Sekabira, K.; Oryem Origa, H.; Basamba, T. A.; Mutumba, G.; Kakudidi, E., (2010). Heavy metal assessment and water quality values in urban stream and rain water. Int. J. Environ. Sci. Tech., 7 (4), 759-770. 